\title{
A new record of Arabis recta Vill. (Brassicaceae) from Poland
}

Anna Wróbel, Ewelina Klichowska, Agnieszka Nobis \& Marcin Nobis

A new record of Arabis recta Vill. (Brassicaceae) from Poland. - Acta Mus. Siles. Sci. Natur., 66: 167$171,2017$.

\begin{abstract}
Arabis recta Vill. is a therophyte currently considered to be endangered in Poland (EN category). The species has been reported from ca. 20 localities situated mainly in the Nida Basin (southeastern Poland). Arabis recta is usually a component of xero-thermophile grasslands, but it can also grow in arable fields or fallows. An abundant population of A. recta was found on slopes of the Góra Sosnówka hill (Małopolska Upland) in 2017. This newly discovered locality is currently the northernmost in Poland. The distribution of A. recta in Poland as well as collected phytosociological documentation are presented.
\end{abstract}

Key words: annual rockcress, threatened species, red-listed species, Małopolska Upland, Central Europe

\section{Introduction}

Arabis recta Vill. (English: annual rockcress) is a species growing mostly in Mediterranean, Pontic and Irano-Turanic biogeographical regions (Meusel et al. 1965). In Central Europe the species reaches the northernmost limit of its range. It is very rare and red-listed in Poland (Kaźmierczakowa et al. 2016), in Germany (Korneck et al. 1996) and in the Czech Republic (Grulich 2012).

The first localities of Arabis recta in Poland were discovered in Skorocice and Przęślin Nature Reserve, both in the Nida Basin (Medwecka-Kornaś 1959). Then, the species was reported from hills near Stawiany in the Nida Basin (Trzcińska-Tacik et al. 1998) and from a railway embankment between Mydlniki and Zabierzów in the Krakowsko-Częstochowska Upland (Kornaś et al. 1959). At the beginning of the $21^{\text {th }}$ century, the occurrence of Arabis recta was confirmed only in Skorocice (Mirek \& Kaźmierczakowa 2001). Due to the decrease in the number of localities and extreme rarity, the species was considered to be critically endangered (CR category) in Poland (Mirek \& Kaźmierczakowa 2001). Later, it was even supposed to become extinct (EX category) (Mirek et al. 2006).

Recent research confirmed the occurrence of $A$. recta in most of the previously known localities situated in the Nida Basin. Moreover, several new localities of the species were recorded in: Winiary, between Bronina and Owczary, Nowa Zagość, Sułkowice, Zagaje Kikowskie, Kików, Górki near Wiślica, between Skowronno and Pińczów, Skowronno Nature Reserve, between Sędziejowice and Chomentówek, near Gartatowice, between Stawiany and Samostrzałów (Nobis et al. 2007; Nobis \& Nobis 2012). In total, the species has been reported from ca. 20 localities scattered in the area of the Nida Basin. It has been estimated that more than one million individuals of the species occur in Poland (Nobis \& Nobis 2012). Thus, Arabis recta is currently regarded as an endangered species (EN category) (Kaźmierczakowa et al. 2014, 2016).

The species grows mostly in the gaps in the xero-thermophile grasslands, and rarely in the arable fields or fallows. The number of individuals observed in successive years may vary considerably (Mirek \& Kaźmierczakowa 2001; Nobis et al. 2007; Nobis \& Nobis 2012). Fluctuations in population size result from differences in weather conditions as well as from 
gaps in plant cover. The latter guarantees successful germination of seeds and is absolutely crucial for the existence of species, because within too dense vegetation Arabis recta is eliminated (Nobis et al. 2007; Nobis \& Nobis 2012).

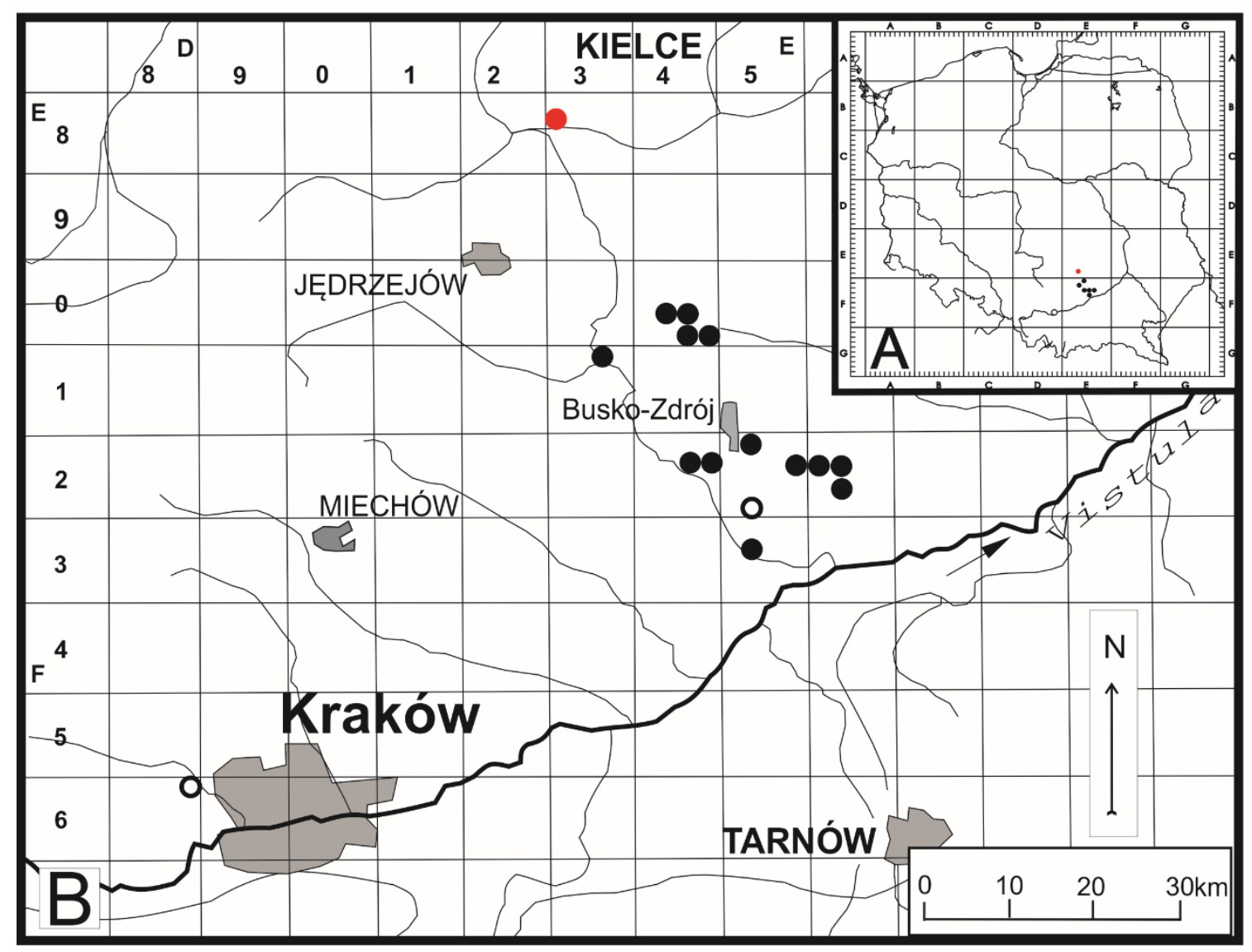

Fig 1: Distribution maps of Arabis recta Vill.: A - in Poland (in the ATPOL grid of squares $10 \mathrm{~km}^{2}$ ), and B - in the Małopolska Upland (in the ATPOL grid of squares $2.5 \mathrm{~km}^{2}$ ); $\bullet$ - locality existing at present; $\bigcirc-$ locality not confirmed; $\bullet$ - new locality

\section{New record}

A new locality of Arabis recta was found on the slopes of the Góra Sosnówka hill, near Chęciny (Kielecka Upland) during field studies conducted in 2017. This locality is currently the northernmost in Poland. The closest localities of $A$. recta are situated ca. $20 \mathrm{~km}$ southwards. Current distribution of the species (Fig. 1) was presented using the ATPOL system, in cartogram units of $10 \mathrm{~km} \times 10 \mathrm{~km}$ and $2.5 \mathrm{~km} \times 2.5 \mathrm{~km}$ (Zając 1978). On the south-eastern, south and south-western facing slopes of the Góra Sosnówka hill more than several hundred individuals of annual rockcress were noted. The species occurs there on limestone soils within grasslands representing Festuco-Brometea class (Fig. 2). Four homogenous patches of vegetation were documented using standard Braun-Blanquet method. All the phytosociological relevés are included in Table 1.

It is worth emphasizing that Arabis recta can be easily overlooked by the botanists during field studies as it is a quite small plant which undergoes very short life cycle lasting approximately six weeks. Thus, it is highly probable that the number of species localities in Poland is much higher than currently stated.

Acknowledgements: The research was funded by the Institute of Botany of the Jagiellonian University (K/ZDS/006305). We would like to thank to Vítězslav Plášek for his help with identification of mosses. 
Tab 1: Plant communities with Arabis recta documented on the slopes of the Góra Sosnówka hill.

\begin{tabular}{|c|c|c|c|c|}
\hline No. of relevé & 1 & 2 & 3 & 4 \\
\hline Date & 15.06 .2017 & 15.06 .2017 & 15.06 .2017 & 15.06 .2017 \\
\hline \multirow{2}{*}{ Geographic coordinates } & $\mathrm{N} 50^{\circ} 48^{\prime} 8.3^{\prime \prime}$ & N 50 48' $8.6^{\prime \prime}$ & N 50॰48' $8.6^{\prime \prime}$ & N 50॰48'8.7’' \\
\hline & E $20^{\circ} 26^{\prime} 6.3^{\prime \prime}$ & E $20^{\circ} 26^{\prime} 12.6^{\prime \prime}$ & E $20^{\circ} 26^{\prime} 12.6^{\prime \prime}$ & $\mathrm{E} 20^{\circ} 26^{\prime} 11.5^{\prime \prime}$ \\
\hline Area of relevé $\left[\mathrm{m}^{2}\right]$ & 4 & 4 & 2 & 4 \\
\hline Exposure & $\mathrm{S}$ & SW & SW & SSW \\
\hline Inclination $\left[{ }^{\circ}\right]$ & 5 & 10 & 10 & 5 \\
\hline Altitude a.s.l. [m] & 283 & 285 & 285 & 284 \\
\hline Cover of C layer [\%] & 70 & 65 & 70 & 65 \\
\hline Cover of D layer [\%] & 60 & 55 & 10 & 50 \\
\hline \multicolumn{5}{|l|}{$\begin{array}{l}\text { Ch. Ass. Sisymbrio-Stipetum } \\
\text { capillatae }\end{array}$} \\
\hline Arabis recta & 1 & 1 & 2 & 1 \\
\hline \multicolumn{5}{|l|}{ Ch. O. Festucetalia valesiacae } \\
\hline Achillea pannonica & . & + & . & . \\
\hline Campanula sibirica & + & + & . & + \\
\hline Potentilla arenaria & + & + & 1 & + \\
\hline Thymus marschallianus & 2 & 1 & 1 & 2 \\
\hline Thesium linophyllon & 2 & 2 & . & 2 \\
\hline \multicolumn{5}{|l|}{ Ch. Cl. Festuco-Brometea } \\
\hline Acinos arvensis & . & + & + & + \\
\hline Anthyllis vulneraria & + & + & . & 1 \\
\hline Arabis hirsuta & . & + & . & . \\
\hline Artemisia campestris & . & + & . & + \\
\hline Asperula cynanchica & 1 & . & . & + \\
\hline Brachypodium pinnatum & 2 & 2 & 1 & . \\
\hline Carex caryophyllea & 2 & 2 & . & 1 \\
\hline Centaurea scabiosa & . & . & 1 & + \\
\hline Centaurea stoebe & 1 & 1 & + & + \\
\hline Dianthus carthusianorum & + & + & + & + \\
\hline Euphorbia cyparissias & 2 & 2 & 2 & . \\
\hline Festuca rupicola & 2 & 2 & 1 & . \\
\hline $\begin{array}{l}\text { Helianthemum nummularium subsp. } \\
\text { obscurum }\end{array}$ & 2 & 2 & 1 & 1 \\
\hline Poa compressa & . & + & 2 & . \\
\hline Saxifraga tridactylites & . & . & . & 1 \\
\hline Veronica spicata & 1 & + & + & 1 \\
\hline \multicolumn{5}{|l|}{$\begin{array}{l}\text { Ch. Cl. Trifolio-Geranietea } \\
\text { sanguinei }\end{array}$} \\
\hline Galium verum & + & 1 & . & . \\
\hline \multicolumn{5}{|l|}{ Ch. et D. All. Geranion sanguinei } \\
\hline Anthericum ramosum & . & + & . & 1 \\
\hline Fragaria viridis & . & + & + & \\
\hline Vincetoxicum hirundinaria & . & + & . & + \\
\hline \multicolumn{5}{|l|}{ Others } \\
\hline Arenaria serpyllifolia var. viscida & . & 1 & 2 & . \\
\hline Asperula tinctoria & . & + & . & . \\
\hline Briza media & + & + & . & 1 \\
\hline $\begin{array}{l}\text { Camelina microcarpa subsp. } \\
\text { sylvestris }\end{array}$ & . & · & 1 & . \\
\hline Chamaecytisus ratisbonensis & + & . & . & . \\
\hline Erigeron acris & . & + & . & . \\
\hline Falcaria vulgaris & + & . & . & . \\
\hline Festuca rubra & . & . & . & 2 \\
\hline Galium boreale & . & . & + & + \\
\hline Hieracium pilosella & + & + & . & . \\
\hline Holosteum umbellatum & + & . & . & . \\
\hline Hypericum perforatum & . & . & + & . \\
\hline
\end{tabular}




\begin{tabular}{|c|c|c|c|c|}
\hline Melampyrum arvense & + & . & + & + \\
\hline Peисеdanит oreoselinum & 1 & . & 1 & + \\
\hline Pimpinella saxifraga & & . & + & . \\
\hline Prunella grandiflora & 2 & . & . & . \\
\hline Salvia pratensis & & + & & \\
\hline Sanguisorba minor & 1 & 2 & 2 & 1 \\
\hline Sanguisorba muricata & & + & 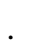 & . \\
\hline Scabiosa sp. & & + & & + \\
\hline Sedum acre & 2 & + & . & . \\
\hline Silene otites & + & + & . & . \\
\hline Mosses and lichens (D) & & & & \\
\hline Abietinella abietina & 3 & 3 & 1 & 3 \\
\hline Ceratodon purpureus & . & + & . & . \\
\hline Didymodon ridigulus & . & $\cdot$ & . & + \\
\hline Fissidens cristatus & . & . & + & \\
\hline Hypnum cupressiforme & & 1 & & 1 \\
\hline Tortella tortuosa & 1 & 1 & & 1 \\
\hline Cladonia sp. & & & & 2 \\
\hline
\end{tabular}

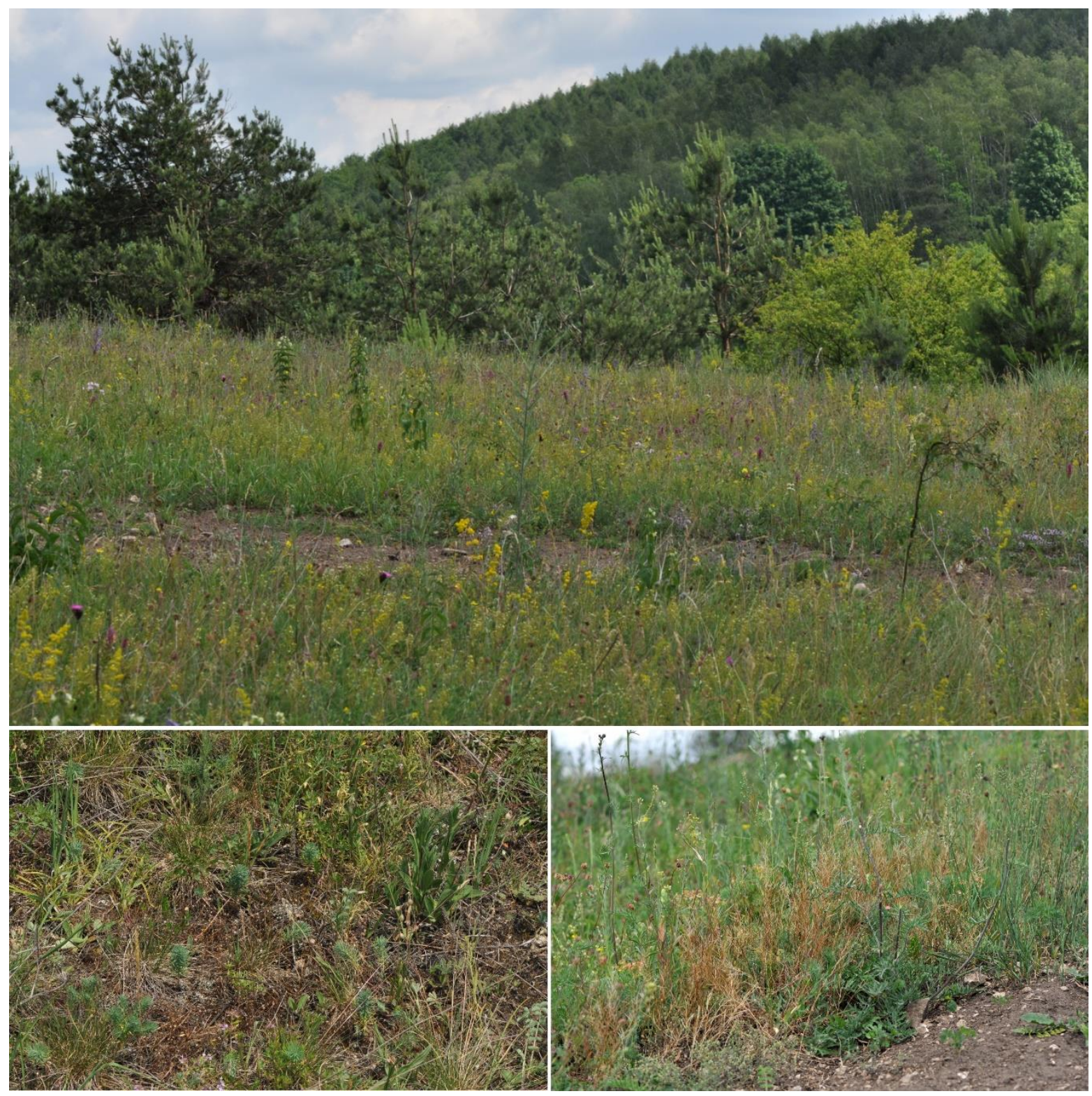

Fig 2: Habitat of Arabis recta Vill. on the Góra Sosnówka hill (photography by M. Nobis, 15.06.2017) 


\section{References}

Grulich V. (2012): Red list of vascular plants of the Czech Republic: $3^{\text {rd }}$ edition. - Preslia 84(3): 631-645.

Kaźmierczakowa R., Bloch-Orłowska J., Celka Z., Cwener A., Dajdok Z., Michalska-Hejduk D., Pawlikowski P., Szczęśniak E. \& Ziarnek K. (2016): Polska czerwona lista paprotników i roślin kwiatowych [Polish red list of pteridophytes and flowering plants]. Institute of Nature Conservation, Polish Academy of Sciences, Kraków.

Kaźmierczakowa R., Mirek Z., Nobis A. \& Nobis M. (2014): Arabis recta Vill. - gęsiówka uszkowata [annual rockcress]. In: Kaźmierczakowa R., Zarzycki K., Mirek Z. (eds). Polska czerwona księga roślin [Polish red data book of plants]. $3^{\text {rd }}$ edition. Institute of Nature Conservation, Polish Academy of Sciences, Kraków, pp. 215-217.

Kornaś J., Leśniowska J. \& Skrzywanek A. (1959): Obserwacje nad florą linii kolejowych i dworców towarowych w Krakowie. Bemerkungen über die Flora der Eisenbahnlinien und Güterbahnhöfe in Kraków. Fragmenta Floristica et Geobotanica 5(2): 199-216.

Korneck D., Schnittler M. \& Vollmer I. (1996): Rote Liste der Farn- und Blütenpflanzen [Red list of ferns and flowering plants] (Pteridophyta et Spermatophyta) Deutschlands [Germany]. - Schriftenreihe für Vegetationskunde 28: 21-187.

Medwecka-Kornaś A. (1959): Roślinność rezerwatu stepowego „Skorocice” koło Buska [Flora of Skorocice Reserve near Busko]. - Ochrona Przyrody 26: 172-260.

Meusel H., Jäger E. \& Weinert E. (1965): Vergleichende Chorologie der zentraleuropäischen Flora [Comparative chorology of Central European flora]. I. Gustav Fischer Verlag, Jena.

Mirek Z. \& Kaźmierczakowa R. (2001): Arabis recta Vill. - gęsiówka uszkowata [annual rockcress]. In: Kaźmierczakowa R., Zarzycki K. (eds). Polska czerwona księga roślin [Polish red data book of plants]. $2^{\text {nd }}$ edition. W. Szafer Institute of Botany, Polish Academy of Sciences, Kraków, pp. 161-163.

Mirek Z., Zarzycki K., Wojewoda W. \& Szeląg Z. (eds). (2006): Czerwona lista roślin i grzybów Polski [Red list of plants and fungi in Poland]. W. Szafer Institute of Botany, Polish Academy of Sciences, Kraków.

Nobis M., Kozak M. \& Bartoszek W. (2007): New data on the distribution of Arabis recta (Brassicaceae) in Poland. - Polish Botanical Journal 52(2): 119-123.

Nobis M. \& Nobis A. (2012): Arabis recta Vill. (Brassicaceae) in Poland: distribution, habitats and threat assessment. - Biodiversity: Research and Conservation 25: 47-54.

Trzcińska-Tacik H., Towpasz K. \& Dostatny D. (1998): Stanowisko interesującej roślinności kserotermicznej w Stawianach koło Pińczowa [A station of the interesting xerotermic vegetation in Stawiany near Pińczów]. - Chrońmy Przyrodę Ojczystą 54(3): 87-90.

Zając A. 1978. Atlas of distribution of vascular plants in Poland (ATPOL). - Taxon 27(5/6): 481-484.

Authors' addresses: Anna Wróbel, Ewelina Klichowska, Agnieszka Nobis \& Marcin Nobis, Institute of Botany, Jagiellonian University, Kopernika 27, 31-501 Kraków, Poland E-mail of corresponding author: m.nobis@uj.edu.pl 